\title{
Sperm competition in honey bees (Apis mellifera L.): the role of body size dimorphism in drones
}

\author{
H. Vasfi GenÇER, Yasin KAHYA \\ Department of Animal Science, Faculty of Agriculture, Ankara University, 06110, Ankara, Turkey
}

Received 20 February 2019 - Revised 24 July 2019 - Accepted 9 October 2019

\begin{abstract}
Previous experimental studies demonstrated that small drones (SD) had lower paternity share since they were not successful in mating with queens as large drones (LD) in the mating arena. However, it remains unclear whether spermatozoa of SD can compete in vivo with those of LD if SD have mating opportunity. We, therefore, tested the spermatozoal competitiveness of SD against LD by instrumentally inseminating the queens with varying proportions of semen from LD and SD. Sister queens from a Buckfast colony and LD and SD from 15 Caucasian colonies were reared synchronously as experimental test individuals. The virgin sister queens were randomly allocated into three semen composition groups. The queens in groups $\mathrm{A}, \mathrm{B}$ and $\mathrm{C}$ were inseminated with an equal volume of semen $(7.2 \mu \mathrm{l})$ collected successively from $6 \mathrm{LD}$ and $6 \mathrm{SD}$ (50\%:50\% treatment), $3 \mathrm{LD}$ and $9 \mathrm{SD}$ (25\%:75\% treatment), and $9 \mathrm{LD}$ and 3 SD (75\%:25\% treatment), respectively. Once oviposition starts in mating nucs, the queens were introduced into field colonies to proceed to lay eggs. After 3 months, about 100 newly emerged worker daughters from each queen were individually collected from the colonies for paternity assignment. Five polymorphic microsatellite loci (A024, A079, A43, A113, and Ap226) were analysed in 144 drones that were used to inseminate 12 experimental queens and 908 offspring workers. The observed patriline frequencies of LD and SD were $67.0 \%$ and $33.0 \%$ in group A, 34.6\% and $65.4 \%$ in group B, and $79.8 \%$ and $20.2 \%$ in group $\mathrm{C}$, respectively. The patriline frequencies within each colony were noticeably skewed. LD that were reared in QRC sired more offspring, whereas SD that were reared in LWC had lower paternity shares. When all three semen composition groups were pooled, the overall observed patriline frequency of SD (40\%) was found to be $10 \%$ less than the overall expected patriline frequency $(50 \%)$. The results demonstrated that SD remained a little behind LD in sperm competition.
\end{abstract}

\section{polyandry / sperm competition / patriline frequency / drone / size dimorphism}

\section{INTRODUCTION}

From an evolutionary point of view, the most important phenomenon in the life of an animal is passing on copies of its genes to the next generation by mating (Sundin 2009). Animal mating systems are complex and strikingly diverse (Shuster and Wade 2003). Polyandry is one of the polygamous mating systems where females mate multiply with

Corresponding author: H. Gençer, gencer@agri.ankara.edu.tr Handling Editor: David Tarpy different males, while males mate only with one female. Polyandry in eusocial insects is of particular interest not only due to its impacts on the intracolonial relationship and the phenotypic consequences of genetic variation at the individual and colony levels but also due to its importance in understanding the evolution of social behaviour (Laidlaw Jr. and Page Jr. 1984; Boomsma and Ratnieks 1996; Page Jr. 2013).

Extreme polyandry is relatively rare among the highly eusocial Hymenoptera (Page Jr. 1986; Boomsma and Ratnieks 1996; Strassmann 2001). Nevertheless, honey bees have evolved extremely high levels of polyandry (Palmer and Oldroyd 2000). The queen honey bee (Apis 
mellifera ) mates with a large number of drones during one or a few nuptial flights in a period of a few days in her early life (Taber 1954; Peer 1956; Woyke 1956, 1962, 1964). During mating action in a drone congregation area (DCA), ejaculates from successive drones are transferred forcefully through the vagina to distensible lateral oviducts (Woyke 1956, 2008). The cumulative ejaculates are temporarily stored in lateral oviducts and probably mixed by muscular contractions of the reproductive tract (Page Jr. 1986; Woyke 2008). Upon returning to the hive, spermatozoa in lateral oviducts migrate gradually into the spermatheca via spermathecal duct in a period of $10-20 \mathrm{~h}$ (Woyke 1962, 1983). The migration of spermatozoa from lateral oviducts into spermatheca is a complex process that is composed of individual spermatozoa movements, abdominal contractions of the queen and the pump of the spermathecal duct, as well as the activity of spermathecal fluid and glands (Laidlaw Jr. 1944; Ruttner and Koeniger 1971; Gessner and Ruttner 1977; Page et al. 1984; Collins 2000). During this process, only $5 \%$ of about $80-100$ million spermatozoa in genital tract reaches the spermatheca, while the rest flows back from lateral oviducts through the vagina (Woyke 1962; Koeniger and Koeniger 1991). In the end, a genetically diverse pool of spermatozoa (4-6 million) are permanently stored alive in spermatheca and used to fertilise eggs up to several years (Ruttner 1956; Woyke 1962).

The reproductive biology of honey bees offers both pre-copulatory (mating competition) and postcopulatory (sperm competition) sexual selection. Polyandry, coupled with unbiased operational sex ratio in favour of drones, leads to intense male-male competition among drones and sperm competition among the ejaculates of drones that mated successfully with the queen (Boomsma et al. 2005). Plenty of drones in a DCA compete to mate with a restricted number of virgin queens (Koeniger et al. 1979). One such DCA was estimated to contain 10,00015,000 drones (Koeniger et al. 2005) coming from about 200 colonies in surrounding apiaries at one time (Baudry et al. 1998).

Sperm competition is the competition between the sperm from two or more males for the fertilisation of the ova of a single female (Parker 1970). Sperm competition is the mechanism of sexual selection causing an increase in genetic relatedness among colony members and the decrease in effective number of matings (Boomsma and Ratnieks 1996). The outcome of such competition is constant overrepresentations of some specific males via their offspring within the colony. Sperm competition is expected to occur during sperm migration process from lateral oviducts to the spermatheca (intraoviductal competition) and during sperm release from spermatheca for fertilising the eggs (intraspermathecal competition) in honey bees (Baer 2005). The prerequisites for both intraoviductal and intraspermathecal sperm competition after multiple copulations are present in honey bee mating biology. The female reproductive tract is a complex competitive arena (Miller and Svensson 2014). The co-occurrence of different ejaculates in the lateral oviducts some distance away from the spermatheca allows intraoviductal sperm competition during sperm migration process (Boomsma et al. 2005; Woyciechowski and Król 1996).

Reproductive success of a drone is the function of the ability to mate with the queen (mating competition) and the quality and quantity of semen enabling competitiveness in inseminating the queen (intraoviductal sperm competition) and fertilising the eggs of the queen (intraspermathecal sperm competition). Drone reproductive quality is defined by the quantity and quality indicators of semen such as ejaculate volume, the number, the concentration, the viability and the length of spermatozoa. These fitness indicators are critical for estimating the inseminating and fertilising ability of a drone. The differences in both semen quantity and quality result in unequal contributions of drones that mated with the queen to the offspring in a colony (Collins 2000; Schlüns et al. 2004; Koffler et al. 2016).

Reproductive potential of drones is associated with body size (Berg et al. 1997; Schlüns et al. 2003; Gençer and Firatli 2005). The body size and the weight of drones are mainly determined by the cell size. The drones emerging from worker cells are smaller in size and weight compared with emerging from drone cells (Berg 1991; Berg et al. 1997; Jarolimek and Otis 2001; Schlüns et al. 2003; McAneney-Lannen 2004; Gençer and Firatli 2005; Herrmann et al. 2005; Zaitoun et al. 2009; Couvillon et al. 2010; Gençer and Kahya 2011; Goins and Schneider 2013). There is a positive 
correlation between body size and the number of spermatozoa in drones (Rinderer et al. 1985; Jarolimek and Otis 2001; Schlüns et al. 2003). Larger and heavier drones produce a higher volume of semen (Gençer and Kahya 2011) with higher number of spermatozoa (Rinderer et al. 1985; Jarolimek and Otis 2001; Schlüns et al. 2003; Gençer and Firatli 2005; Zaitoun et al. 2009; Gençer and Kahya 2011) compared with smaller and lighter drones. SD are $36.6 \%$ lighter in weight and produce $28.2 \%$ fewer spermatozoa than LD (Gençer and Firatli 2005). Interestingly, however, SD have $20 \%$ more spermatozoa per milligramme body mass than LD (Schlüns et al. 2003). Similarly, compound eye size and the diameter of facets are relatively larger in SD than $\mathrm{LD}$ in relation to body size (Streinzer and Spaethe 2015). Besides, the drones heavier at emergence have a longer life span enabling competitive advantage (Czekońska et al. 2019).

Flight ability of drones is of importance regarding mating opportunity and male-male competition (Coelho 1996). Flight ability varies among drones. The duration and frequency of flight in drones decrease with increasing inbreeding (Moritz 1981). Body size may also affect the flight power of drones. The drones use more concentrated nectar as fuel for the flight muscles to secure longer mating flights (Hayashi et al. 2016). Thorax weight and thorax/body weight ratio may affect flight ability and mating success (Slone et al. 2012). SD have narrower thorax and smaller compound eyes than LD (Streinzer and Spaethe 2015). LD may have better flight ability and visual power enabling competitive advantage at DCA. Smaller wings (Berg et al. 1997; Schlüns et al. 2003), smaller lenses (Streinzer and Spaethe 2015) and higher wing fluctuating asymmetry (Jaffé and Moritz 2010) may restrict the ability to access to the virgin queen. However, Jarolimek and Otis (2001) did not find any difference between LD and SD in average flight duration, total flight duration, number of flights per day and maximum flight duration.

Paternity share in a colony demonstrates the reproductive success of individual drones. Berg et al. (1997) suggested that reproductive success of SD was lower than that of LD since SD were less competitive in accessing the queen during copulation, although spatial and temporal distributions of LD and SD in DCA were not different. According to Jarolimek and Otis (2001), a lower number of spermatozoa in SD alone may account for the lower reproductive success of SD. The natural presence ratio of SD to LD in a DCA was estimated to be about 1:10 (Berg 1991). Couvillon et al. (2010) determined that SD achieved approximately half as many matings as expected (much less than the natural presence ratio of SD), considering their number of flights, and had a significantly lower paternity share per mating than LD. In the experiment designed by mimicking the presence ratio of SD to LD (1:10) in a semi-isolated DCA (Couvillon et al. 2010), the 29 experimental queens unexpectedly mated mostly with non-experimental drones (about $80 \%$ of the total fathers), indicating the unintentional inclusion of drones from unknown colonies. Now that the types of these uncontrolled drones were uncertain (most likely LD), the proportion of SD to $\mathrm{LD}$ in the DCA was doubtful. The presence ratio of SD in the DCA was likely much less than $10 \%$ even if their flight activities were more temporarily uniform than LD in that experiment.

Previous studies (Berg et al. 1997; Couvillon et al. 2010) demonstrated the lower paternity share of SD in natural populations. However, it remains unclear whether this lower paternity share is due only to inferior mating competition. In both studies, SD did not get the opportunity for sperm competition as a result of inferior mating success. Therefore, it is still not known whether SD spermatozoa can compete with LD spermatozoa if both LD and SD have equal opportunity for inseminating the queens, although SD have reduced reproductive potential.

Here, in this study, we investigated the effect of male size dimorphism on sperm competition in particular honey bees. In the experiment, we used the instrumental insemination technique to give the insemination opportunity to SD by eliminating the mating barrier causing unequal transfer of sperm during copulation. Instrumental insemination also allowed us to use the known drones in terms of race and age. We quantified to what extent the spermatozoal competitiveness of SD against LD when groups of test queens were instrumentally inseminated with various 
proportions of semen from these two types of drones. We inseminated the test queens especially with successively collected semen without a homogenising process to detect the effect of the positions of drones in the insemination sequence on paternity share, corresponding to the issue of last male precedence in natural mating condition. Furthermore, we were able to quantify the reproductive success of drone mother colonies by registering the numbers of mother colonies of individual drones that were used in inseminations.

\section{MATERIAL AND METHODS}

\subsection{Drone rearing}

We synchronously produced two morpho-types of drones with respect to body size (large drones, LD, and small drones, SD). The following arrangements were conducted to obtain a plentiful of sexually mature LD and SD in our apiary at Ankara University. During the spring season, 15 equalsized Caucasian (Apis mellifera caucasica) colonies were selected as potential drone producer colonies. When these colonies reached to full strength occupying one standard Langstroth hive body, random 3 out of them were stimulated to become laying worker colonies (LWC) for producing SD by dequeening and removing their unsealed brood frames. The other 12 colonies were maintained as queenright colonies (QRC) for producing LD. The dequeened colonies were monitored regularly to identify the date the workers commenced egg-laying. Once they became LWC, the queen of each QRC was confined on an empty drone comb by a queen excluder cage to induce a large quantity of unfertilised egg-laying. When both sides of the combs were completely occupied with eggs within 2 days, the queens were released by removing queen excluder cages, and the drone combs with eggs were left in their hives for brood development until emergence.

Obtaining drone brood by queen confinement in all 12 QRC was successively accomplished within a week. One day before the anticipated date of eclosion, the experimental drone comb in each QRC was again placed into queen excluder cage and returned to its hive. This practice enabled us to obtain drones en masse by not letting them disperse in the hive. The following day, the comb was taken from queen excluder cage in the hive, and the cohort of LD eclosed from this comb within $24 \mathrm{~h}$ was gathered and marked on the thorax with a paint marker (Edding 751). Concurrently, SD eclosing from worker cells in LWC were collected from their hives and then marked. When marking, one of the combinations of paint colour (yellow, blue, turquoise or red), the position (left, centre or right) and the number (single or double) of dot on the thorax were preferred for each drone mother colony. With this scheme (Figure 1), marked drones could be discriminated by a unique colony-specific marking.

Once marked, the drones were released back in their mother colonies for fostering. Since keeping drones in confinement may undesirably affect maturation and life span, the marked drones were allowed to fly freely outside their hives until 1 day

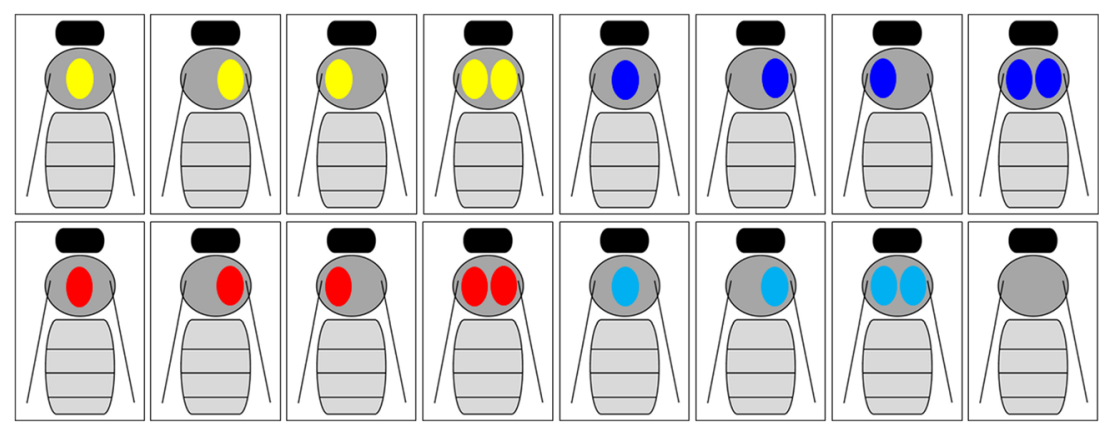

Figure 1. Marking arrangements of drones. Each of 15 drone mother colonies was indicated by unique marking, which is one of the combinations of paint colour (yellow, blue, red or turquoise), dot position (left, centre or right) and the number (single or double) of dot on the thorax of the drone. The drones from each mother colony carried one of these specific markings. 
before use. With this procedure, we provided them with natural ambience during the sexual maturation process. We marked many more drones as a precaution to the probable loss of drones due to the allowance of free-flying until insemination procedure. This precaution also provided us to inseminate more queens in case of unexpected queen loss in various steps from insemination through offspring sampling. In total, 11100 drones (7200 LD from 12 QRC and 3900 SD from 3 LWC) were marked.

\subsection{Queen rearing and instrumental insemination}

Queen rearing was synchronised with drone rearing to coincide the sexual maturity of experimental queens and drones. A batch of experimental test queens were reared from a Buckfast colony that was unrelated to drone producing colonies by standard grafting method (Laidlaw and Page 1997), expecting virgin queens to possess different alleles from both LD and SD. The queen cells were introduced into Kirchain polystyrene mating nucs that have four small combs covered with worker bees 1 day before emergence. The flight entrances of all mating nucs were closed with a queen excluder to prevent queens from free-flying. One day before insemination procedures, the marked drones were collected from all QRC and LWC and arrested in a 5-frame foster hive that was supplied with three frames of unsealed honey combs slightly covered by young workers. This foster hive was taken into the laboratory during semen collection and insemination procedure. Forty virgin sister queens in mating nucs were randomly allocated to three treatment groups (Figure $2 \mathrm{a}-\mathrm{c}$ ). The experimental queens were inseminated 6 days post-eclosion with proportionally different mixtures of LD and SD semen using a standard instrumental insemination instrument (Peter Schley Equipment, Lich, Germany).

Each queen was inseminated with $7.2 \mu \mathrm{l}$ semen collected successively from 12 drones. An equal volume of semen $(0.6 \mu \mathrm{l})$ was taken from both LD and SD. The precise volume of semen $(0.6 \mu \mathrm{l})$ taken from each drone was measured by Gilmont micrometre (Gilmont Instruments; Barrington, IL, USA) connected to Harbo syringe. The queens in group A were inseminated with the semen from $6 \mathrm{LD}$ and $6 \mathrm{SD}(3.6 \mu \mathrm{LD}: 3.6 \mu \mathrm{l}$ S; $1: 1$ treatment). The order in which the semen was collected alternately from $6 \mathrm{LD}$ and $6 \mathrm{SD}$ into the syringe tip for queens in group A was LD1 + LD2 + $\mathrm{SD} 1+\mathrm{SD} 1+\mathrm{LD} 3+\mathrm{LD} 4+\mathrm{SD} 2+\mathrm{SD} 2+\mathrm{LD} 5+$ $\mathrm{LD} 6+\mathrm{SD} 3+\mathrm{SD} 3$, where the different numbers denote different drone mother colonies of each LD and SD. The queens in group B were inseminated

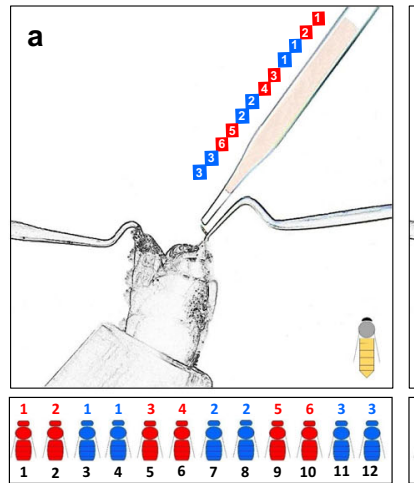

$6 \times 0.6 \mu \mathrm{l}=3.6 \mu \mathrm{l}(50 \%)$ $6 \times 0.6 \mu \mathrm{l}=3.6 \mu \mathrm{l}(50 \%)$
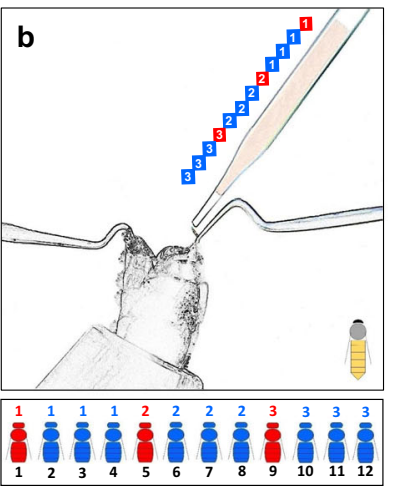

$3 \times 0.6 \mu \mathrm{l}=1.8 \mu \mathrm{l}(25 \%)$ $9 \times 0.6 \mu \mathrm{l}=5.4 \mu \mathrm{l}(75 \%)$
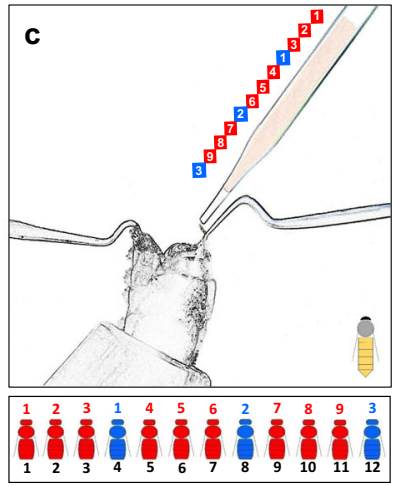

$9 \times 0.6 \mu \mathrm{l}=5.4 \mu \mathrm{l}(75 \%)$ $3 \times 0.6 \mu \mathrm{l}=1.8 \mu \mathrm{l}(25 \%)$

Figure 2. Schematic illustration of treatment groups $(\mathbf{a}, \mathbf{b}$ and $\mathbf{c})$. The numbers over drone images denote the drone mother colonies of each large drone (red) and small drone (blue). The numbers under drone images denote the sequence of drones in semen collection step. Red and blue squares with numbers demonstrate the positions of semen portions in the syringe tip. 
with semen from 3 LD and 9 SD (1.8 $\mu$ LD:5.4 $\mu \mathrm{l}$ $\mathrm{SD} ; 1: 3$ treatment). The semen collection order was $\mathrm{LD} 1+\mathrm{SD} 1+\mathrm{SD} 1+\mathrm{SD} 1+\mathrm{LD} 2+\mathrm{SD} 2+\mathrm{SD} 2+$ $\mathrm{SD} 2+\mathrm{LD} 3+\mathrm{SD} 3+\mathrm{SD} 3+\mathrm{SD} 3$ in group $\mathrm{B}$. The composition of semen that were injected to the queens in group $\mathrm{C}$ was from $9 \mathrm{LD}$ and $3 \mathrm{SD}$ (5.4 $\mu \mathrm{LDD}: 1.8 \mu \mathrm{l} \mathrm{SD} ; 3: 1$ treatment) and the semen collection order was $\mathrm{LD} 1+\mathrm{LD} 2+\mathrm{LD} 3+\mathrm{SD} 1+$ $\mathrm{LD} 4$ + LD5 + LD6 + SD2 + LD7 + LD8 + LD9 + SD3. In this way, both LD and SD equally contributed to the total volume of semen in group A, whereas LD contributed $25 \%$ of the total volume and SD contributed $75 \%$ in group $\mathrm{B}$, and vice versa in group $\mathrm{C}$.

Each drone that was used to inseminate each queen which was kept individually in a microcentrifuge tube filled with $96 \%$ ethanol $\left(-20^{\circ} \mathrm{C}\right)$ after recording its sequence in semen combination and mother colony number (Table I). We aimed to obtain 4 instrumentally inseminated queens per semen combination group (12 queens in 3 groups) for paternity analysis. As we took into account the probable queen loss at several steps until sampling of their offspring, we inseminated more queens than aimed. In total, 39 queens were inseminated: 14 queens with $1: 1$ proportion of $\mathrm{LD}$ and SD semen (A), 13 queens with 1:3 proportion of LD and SD semen (B) and 12 queens with 3:1 proportion of LD and SD semen (C). We took 144 drones from 9 of 12 QRC (colony numbers 1, 2, 4, $6,7,13,22,25$ and 29) and 3 LWC (colony numbers 12, 24 and 38) to inseminate 12 experimental queens. Four drones from each of QRC 4, 22 and 25; 8 drones from each of QRC 1, 2 and 29; 12 drones from each of QRC 6, 7 and 13; and 24 drones from each of LWC 12, 24 and 38 were used as potential fathers (Table I).

Upon each insemination, the queens were returned to their mating nuclei. All inseminated queens commenced to oviposit within 10 days, except for one queen from group A and two queens from group B. When the test queens started to oviposit in mating nuclei, 34 of them $(11,11$ and 12 queens in $\mathrm{A}, \mathrm{B}$, and $\mathrm{C}$, respectively) were introduced into equally strong field colonies in standard Langstroth hives. Before introduction, each queen was marked with a numbered disc stuck on her thorax, and the distal portion of the right fore wing was clipped to recognise if any superseding happened throughout the season. In this way, any uncontrolled matrilineal sampling was not allowed.

Table I. The hive (colony) numbers of drone mother colonies (QRC and LWC) of 72 LD and 72 SD that were used to inseminate 12 experimental queens in semen combination groups $\mathrm{A}, \mathrm{B}$ and $\mathrm{C}$. The numbers from 1 to 12 in the first line refer to the drone order in the semen collection step of instrumental insemination procedure. In bold are the colony numbers of QRC, and in italics are the colony numbers of LWC

\begin{tabular}{lcccccccccccc}
\hline Queens & \multicolumn{10}{c}{ The colony number of drone mother colonies } \\
\cline { 2 - 12 } & 1 & 2 & 3 & 4 & 5 & 6 & 7 & 8 & 9 & 10 & 11 & 12 \\
\hline A-Q1 & $\mathbf{1}$ & $\mathbf{7}$ & 12 & 12 & $\mathbf{6}$ & $\mathbf{1 3}$ & 38 & 38 & $\mathbf{2}$ & $\mathbf{2 9}$ & 24 & 24 \\
A-Q2 & $\mathbf{1}$ & $\mathbf{7}$ & 38 & 38 & $\mathbf{6}$ & $\mathbf{1 3}$ & 12 & 12 & $\mathbf{2}$ & $\mathbf{2 9}$ & 24 & 24 \\
A-Q3 & $\mathbf{1}$ & $\mathbf{7}$ & 24 & 24 & $\mathbf{6}$ & $\mathbf{1 3}$ & 38 & 38 & $\mathbf{2}$ & $\mathbf{2 9}$ & 12 & 12 \\
A-Q4 & $\mathbf{1}$ & $\mathbf{7}$ & 24 & 24 & $\mathbf{6}$ & $\mathbf{1 3}$ & 12 & 12 & $\mathbf{2}$ & $\mathbf{2 9}$ & 38 & 38 \\
B-Q1 & $\mathbf{7}$ & 24 & 24 & 24 & $\mathbf{6}$ & 38 & 38 & 38 & $\mathbf{1 3}$ & 12 & 12 & 12 \\
B-Q2 & $\mathbf{7}$ & 24 & 24 & 24 & $\mathbf{6}$ & 38 & 38 & 38 & $\mathbf{1 3}$ & 12 & 12 & 12 \\
B-Q3 & $\mathbf{7}$ & 38 & 38 & 38 & $\mathbf{6}$ & 12 & 12 & 12 & $\mathbf{1 3}$ & 24 & 24 & 24 \\
B-Q4 & $\mathbf{7}$ & 38 & 38 & 38 & $\mathbf{6}$ & 12 & 12 & 12 & $\mathbf{1 3}$ & 24 & 24 & 24 \\
C-Q1 & $\mathbf{1}$ & $\mathbf{7}$ & $\mathbf{6}$ & 38 & $\mathbf{1 3}$ & $\mathbf{2}$ & $\mathbf{2 9}$ & 24 & $\mathbf{4}$ & $\mathbf{2 2}$ & $\mathbf{2 5}$ & 12 \\
C-Q2 & $\mathbf{1}$ & $\mathbf{7}$ & $\mathbf{6}$ & 24 & $\mathbf{1 3}$ & $\mathbf{2}$ & $\mathbf{2 9}$ & 12 & $\mathbf{4}$ & $\mathbf{2 2}$ & $\mathbf{2 5}$ & 38 \\
C-Q3 & $\mathbf{1}$ & $\mathbf{7}$ & $\mathbf{6}$ & 12 & $\mathbf{1 3}$ & $\mathbf{2}$ & $\mathbf{2 9}$ & 38 & $\mathbf{4}$ & $\mathbf{2 2}$ & $\mathbf{2 5}$ & 24 \\
C-Q4 & $\mathbf{1}$ & $\mathbf{7}$ & $\mathbf{6}$ & 12 & $\mathbf{1 3}$ & $\mathbf{2}$ & $\mathbf{2 9}$ & 38 & $\mathbf{4}$ & $\mathbf{2 2}$ & $\mathbf{2 5}$ & 24 \\
\hline
\end{tabular}




\subsection{Sampling and genetic analyses}

The offspring samples of 34 experimental queens were taken for quantifying the patriline frequency of LD and SD. Sampling was done 3 months after onset of oviposition, paying attention to the report by Franck et al. (1999) that sperm admixture in spermatheca of the queen was incomplete at the beginning of egg-laying. Before sampling, the instrumentally inseminated queens and egg-laying patterns in their colonies were checked. Not any instrumentally inseminated queens were superseded throughout the season, and all queens displayed normal egg-laying performance, indicated by the presence of compact sealed worker brood and the absence of drone pupae in worker cells. About 100 newly emerged offspring workers were taken from each colony. The sample workers were kept in glass jars filled with $96 \%$ ethanol $\left(-20^{\circ} \mathrm{C}\right)$ until microsatellite DNA analysis. The offspring samples of randomly selected four experimental queens from each insemination group (12 of 34 queens) were analysed.

The nuclear DNA was extracted from the thoraces of 144 drones (72 LD and $72 \mathrm{SD}$ ) that were used to inseminate 12 experimental queens and 75-80 workers of each experimental queen by phenol-chloroform method (Hall 1986). Each individual was genotyped with five microsatellite loci (A079, A113, A024, Ap226 and A43; Estoup et al. (1995); Solignac et al. (2003)). DNA of each individual was amplified with fluorescence dyelabelled primers using standard PCR protocols. Allelic DNA fragment sizes were scored in automated capillary electrophoresis (Beckman CEQTM 8000 Genetic Analyser). The numbers and frequencies of alleles of five microsatellite loci were determined by Cervus 3.0.3 software (Kalinowski et al. 2007). The sire of each worker was identified by using COLONY 2.0.1.2 software (Wang 2004). The allele combinations of inseminated queens were inferred from the genotypes of worker progeny and siring drones.

\subsection{Statistical analyses}

The proportions of the worker offspring sired by each drone inseminating each queen (patriline frequency) in semen combination groups A, B and $\mathrm{C}$ were calculated. The patriline frequencies were normalised by arcsin transformation. The transformed frequencies were applied to nested ANOVA (injection sequence within drone morph within semen combination group), followed by least significant difference. Reproductive success of drone mother colonies was quantified by using the records indicating the mother colony of each drone used during insemination procedure (Table I) and the proportion of worker offspring sired by each drone. The number of offspring per drone in each mother colony and the unit offspring proportion of drones from each mother colony were calculated as the representations of male reproductive success at the colony level. The reproductive success data of QRC and LWC were compared with Student's $t$ test. Type I error was delimited at $\alpha=0.05$ in both nested ANOVA and Student's $t$ test. All statistical analyses were performed using Minitab 17 software package.

\section{RESULTS}

In total, 144 paternal drones and 908 offspring workers (300, 301 and 307 in A, B and C groups, respectively) were genotyped with five microsatellite loci. On average, 76 daughters per queen were analysed (minimum 71 , maximum 82 ). The five microsatellite loci analysed presented adequate polymorphism to discriminate all paternal genotypes. The allele sizes (bp) and allele frequencies of five microsatellite loci determined in 908 offspring workers were presented in Table II. A113 was found to be the highest polymorphic locus with 11 alleles (size range from 211 to $233 \mathrm{bp}$ ). The lowest polymorphic locus was Ap226 (238-246 bp) with only three alleles.

There was not any drone having identical allele combination with another one, so all 144 drones could be differentiated genetically by five microsatellite markers. Accordingly, the patriline of each offspring worker could be uniquely assigned to one of the genetically marked siring drones.

The proportions of the worker offspring sired by each drone inseminating each queen in semen combination group A (50\%:50\%; LD:SD) were presented in Table III. Of the total 300 workers from four queens, 201 workers were sired by LD, and SD sired 99 workers. LD sired $67.0 \%$ of 
Table II. Allele lengths (bp) and allele frequencies of five microsatellite loci of daughter workers

\begin{tabular}{|c|c|c|c|c|c|c|c|c|c|}
\hline \multicolumn{2}{|c|}{ Ap226 } & \multicolumn{2}{|c|}{ A43 } & \multicolumn{2}{|c|}{ A024 } & \multicolumn{2}{|c|}{ A079 } & \multicolumn{2}{|c|}{ A113 } \\
\hline $\mathrm{bp}$ & $\mathrm{f}$ & $\mathrm{bp}$ & $\mathrm{f}$ & $\mathrm{bp}$ & $\mathrm{f}$ & $\mathrm{bp}$ & $\mathrm{f}$ & $\mathrm{bp}$ & $\mathrm{f}$ \\
\hline 238 & 0.0890 & 136 & 0.0055 & 94 & 0.1993 & 97 & 0.3434 & 211 & 0.0060 \\
\hline 244 & 0.8777 & 138 & 0.9432 & 100 & 0.0512 & 101 & 0.4080 & 213 & 0.0382 \\
\hline \multirow[t]{9}{*}{246} & 0.0330 & 140 & 0.0398 & 102 & 0.1900 & 103 & 0.2278 & 217 & 0.0197 \\
\hline & & 142 & 0.0115 & 104 & 0.5479 & 105 & 0.0099 & 219 & 0.1894 \\
\hline & & & & 106 & 0.0116 & 121 & 0.011 & 221 & 0.0497 \\
\hline & & & & & & & & 223 & 0.0409 \\
\hline & & & & & & & & 225 & 0.3996 \\
\hline & & & & & & & & 227 & 0.0759 \\
\hline & & & & & & & & 229 & 0.0764 \\
\hline & & & & & & & & 231 & 0.0737 \\
\hline & & & & & & & & 233 & 0.0306 \\
\hline
\end{tabular}

offspring in contrast to the expected proportion (50\%, Figure 3$)$. The observed proportion of workers that were sired by SD $(33.0 \%)$ was significantly lower $(17 \%)$ than the expected $(50 \%)$, although the queens were inseminated with equal volumes of semen from equal numbers of LD and
SD. On average, the relative contribution of SD to offspring was $66 \%$ of their expected contribution.

The patriline frequencies in queens that were inseminated with mixed semen from 25\% LD and $75 \%$ SD were presented in Table IV. Of the total 301 workers from four queens, 104 offspring

Table III. Patriline frequencies (\%) and the total numbers of worker offspring genotyped for each queen that was instrumentally inseminated with semen of $\mathrm{LD}(50 \%)$ and $\mathrm{SD}(50 \%)$. The drone numbers refer to the sequence in the semen collection step. The reverse sequence corresponds to the injection sequence in the injection step

\begin{tabular}{lccccc}
\hline Semen sequence (drone morph) & Queen 1 & Queen 2 & Queen 3 & Queen 4 & Total \\
\hline Drone 1 (LD1) & 54.17 & 0.00 & 2.67 & 12.68 & 16.67 \\
Drone 2 (LD2) & 1.39 & 3.66 & 12.00 & 2.82 & 5.00 \\
Drone 3 (SD1) & 2.78 & 1.22 & 6.67 & 4.23 & 3.67 \\
Drone 4 (SD1) & 5.56 & 0.00 & 21.33 & 0.00 & 6.67 \\
Drone 5 (LD3) & 6.94 & 3.66 & 1.33 & 23.94 & 8.67 \\
Drone 6 (LD4) & 2.78 & 57.32 & 12.00 & 18.31 & 23.66 \\
Drone 7 (SD2) & 1.39 & 0.00 & 14.67 & 19.72 & 8.67 \\
Drone 8 (SD2) & 1.39 & 4.88 & 5.33 & 0.00 & 3.00 \\
Drone 9 (LD5) & 1.39 & 12.20 & 5.33 & 12.68 & 8.00 \\
Drone 10 (LD6) & 2.78 & 4.88 & 10.67 & 1.41 & 5.00 \\
Drone 11 (SD3) & 2.78 & 12.20 & 4.00 & 2.82 & 5.67 \\
Drone 12 (SD3) & 16.67 & 0.00 & 4.00 & 1.41 & 5.33 \\
Total LD & 69.4 & 81.7 & 44.0 & 71.8 & 67.0 \\
Total SD & 30.6 & 18.3 & 56.0 & 28.2 & 33.0 \\
Total offspring $(n)$ & 72 & 82 & 75 & 71 & 300 \\
\hline
\end{tabular}




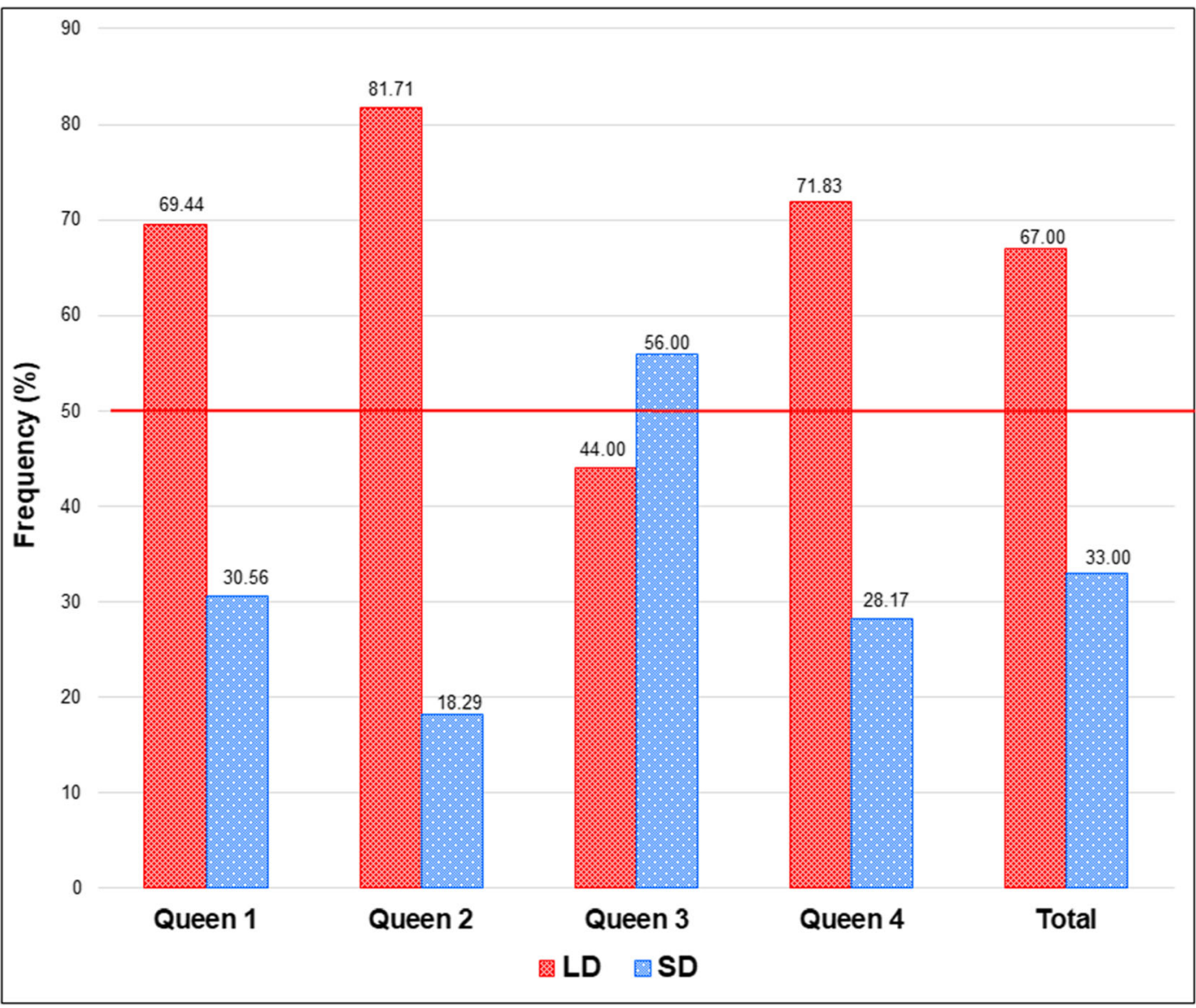

Figure 3. Proportions of offspring sired by large drones (LD) and small drones (SD) that were used to inseminate 4 queens with the mixture of 50\% LD and 50\% SD semen. Horizontal red line refers to expected patriline frequency level for both LD and SD.

workers were sired by LD and 197 offspring workers were sired by SD. The patriline frequencies of LD and SD were $34.6 \%$ and $65.4 \%$, respectively (Figure 4). As expected, the worker daughters sired by SD were more than those sired by LD. However, the patrilines were not distributed harmoniously with the proportions of semen from LD and SD (25\%:75\%) that were injected to the queens. The observed proportion of workers sired by SD was $9.6 \%$ less than the expected proportion. On average, the relative contribution of SD to offspring was $87.2 \%$ of their expected contribution.

Proportions of offspring sired by LD and SD that were used to inseminate 4 queens with mixed semen from $75 \% \mathrm{LD}$ and $25 \%$ SD were presented in Table V. Of the total 307 workers from four queens that were inseminated with $75 \% \mathrm{LD}$ and $25 \%$ SD semen mixture, 245 were sired by LD, and the remaining 62 were sired by SD. The observed patriline frequencies of LD and SD were $79.8 \%$ and $20.2 \%$, respectively (Figure 5). SD contributed $4.8 \%$ less offspring than expected.

When three semen composition groups were pooled, 550 of the total 908 workers from 12 queens were sired by LD, whereas SD sired remaining 358 workers. The overall observed patriline frequencies of LD and SD were found to be $60.5 \%$ and $39.5 \%$, respectively. The overall observed patriline frequency of SD was $10.5 \%$ less than the overall expected patriline frequency. The overall relative contribution of SD to offspring was $79.0 \%$ of their expected contribution. 
Table IV. Patriline frequencies (\%) and the total numbers of worker offspring genotyped for each queen that was instrumentally inseminated with semen of $\mathrm{LD}(25 \%)$ and SD $(75 \%)$. The drone numbers refer to the sequence in the semen collection step. The reverse sequence corresponds to the injection sequence in the injection step

\begin{tabular}{lccccc}
\hline Semen sequence (drone morph) & Queen 1 & Queen 2 & Queen 3 & Queen 4 & Total \\
\hline Drone 1 (LD1) & 17.72 & 8.33 & 12.99 & 12.33 & 12.96 \\
Drone 2 (SD1) & 3.80 & 5.56 & 6.49 & 4.11 & 4.98 \\
Drone 3 (SD1) & 3.80 & 1.39 & 12.99 & 2.74 & 5.32 \\
Drone 4 (SD1) & 3.80 & 16.67 & 5.19 & 10.96 & 8.97 \\
Drone 5 (LD2) & 13.92 & 6.94 & 2.60 & 6.85 & 7.64 \\
Drone 6 (SD2) & 11.39 & 12.50 & 3.90 & 1.37 & 7.31 \\
Drone 7 (SD2) & 6.33 & 13.89 & 9.09 & 19.18 & 11.96 \\
Drone 8 (SD2) & 5.06 & 5.56 & 7.79 & 10.96 & 7.31 \\
Drone 9 (LD3) & 12.66 & 13.89 & 15.58 & 13.70 & 13.95 \\
Drone 10 (SD3) & 3.80 & 6.94 & 7.79 & 6.85 & 6.31 \\
Drone 11 (SD3) & 2.53 & 2.78 & 6.49 & 6.85 & 4.65 \\
Drone 12 (SD3) & 15.19 & 5.56 & 9.09 & 4.11 & 8.64 \\
Total LD & 44.3 & 29.2 & 31.2 & 32.9 & 34.6 \\
Total SD & 55.7 & 70.8 & 68.8 & 67.1 & 65.4 \\
Total offspring $(n)$ & 79 & 72 & 77 & 73 & 301 \\
\hline
\end{tabular}

The data showed that the patriline frequencies in all colonies were not in accordance with the proportions of LD and SD semen injected into the experimental queens. There was a clear difference between SD and LD in patriline frequency. In all semen combination groups, LD were consistently overrepresented in offspring. More than $50 \%$ of workers produced by queens had LD paternity. The nested ANOVA revealed that the drone morph was a significant factor $(F=1.770, P=$ 0.021 ) affecting the patriline frequencies in all experimentally established semen combination groups. Nevertheless, the presented data did not reveal any significant effect of the positions of drones in the insemination sequence on the patriline frequencies $(F=0.719, P=0.850)$. The last inseminating drone sired neither more nor fewer offspring than the other drones.

Reproductive success of drone mother colonies (QRC and LWC) was presented in Table VI. The mean number of offspring per drone in QRC was 7.08, whereas it was 4.97 in LWC. However, the difference in the number of offspring per drone between QRC and LWC (2.11) was not found to be statistically significant. No significant difference was also found between QRC and LWC in the unit offspring proportion of drones. The number of offspring per drone ranged from 3.75 to 13.25 among QRC, while it ranged from 5.04 to 5.21 among LWC. The highest number of offspring per drone (13.25) was determined in QRC 1, and QRC 25 had the lowest number of offspring per drone (3.75).

\section{DISCUSSION}

Several studies were conducted in honey bees on sperm competition (Moritz 1986; Harbo 1988, 1990; Woyciechowski and Król 1996; Franck et al. 2002) or sperm utilisation of the queen (Laidlaw Jr. and Page Jr. 1984; Haberl and Tautz 1998; Page Jr. and Metcalf 1982; Koeniger et al. 1992; Sasaki et al. 1995; Schlüns et al. 2004; Holmes et al. 2011; Brodschneider et al. 2012; Baer et al. 2016). Some authors did not report any evidence for sperm competition (Moritz 1986; Page Jr. and Metcalf 1982; Laidlaw Jr. and Page Jr. 1984; Sasaki et al. 1995; Woyciechowski and Król 1996; Haberl and Tautz 1998; Franck et al. 1999, 2002; Shafir et al. 2009; Holmes et al. 2011), whereas some others interpreted the variation in subfamily distributions (Harbo 1988, 1990; 


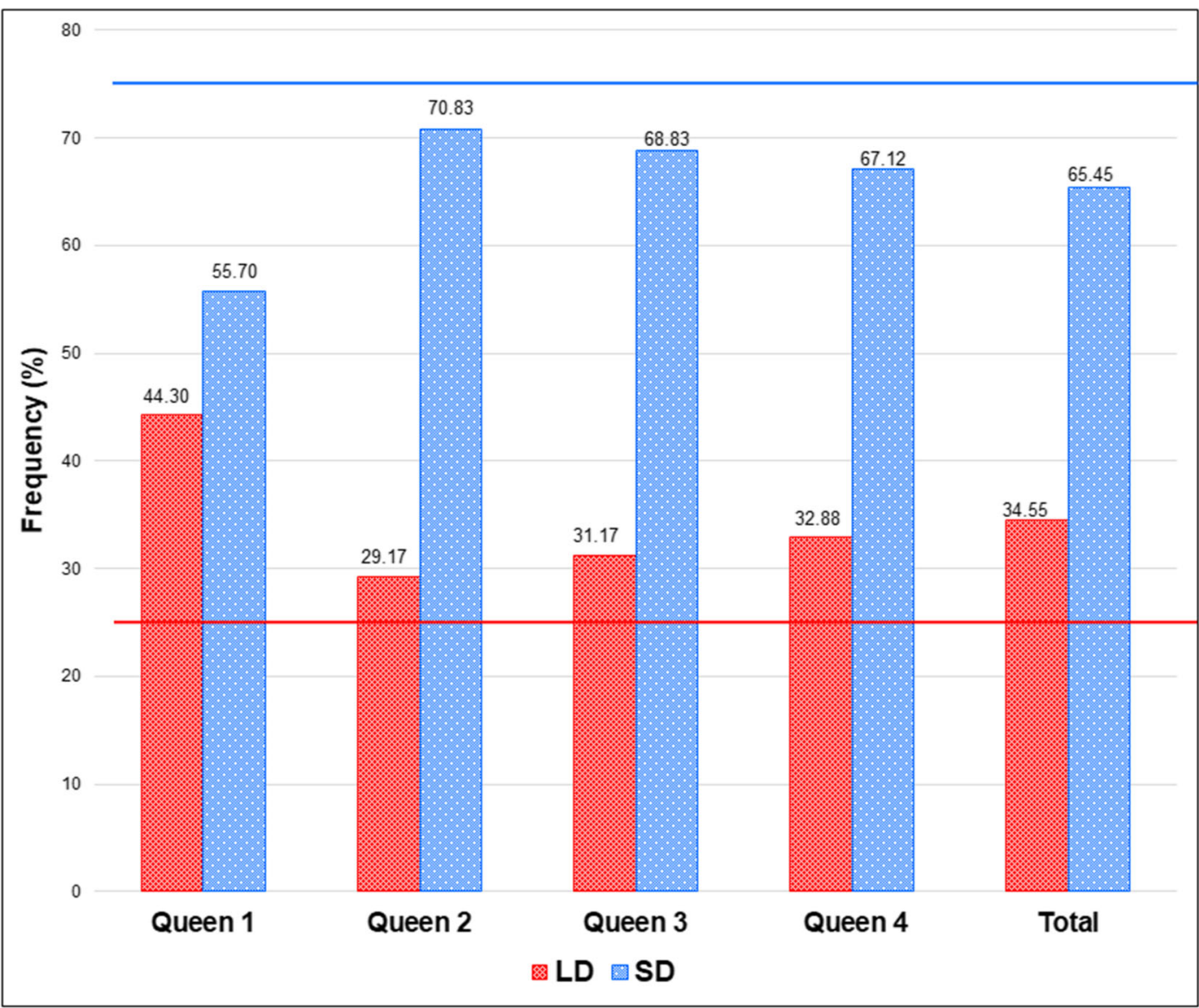

Figure 4. Proportions of offspring sired by large drones (LD) and small drones (SD) that were used to inseminate 4 queens with the mixture of 25\% LD and 75\% SD semen. Horizontal red line refers to expected patriline frequency level for LD and horizontal blue line for SD.

DeGrandi-Hoffman et al. 2003; Schlüns et al. 2004; Couvillon et al. 2010; Brodschneider et al. 2012) and the results of in vitro spermatozoa tests (Tofilski et al. 2012) as the consequence of sperm competition.

Our present results confirmed the existence of sperm competition in honey bees. We presented here clear empirical evidence on sperm competition using two drone morphs that reproductive potentials are distinct. Our present data demonstrated the skew in patriline distributions within each colony, indicating sperm competition. LD that were reared in QRC sired more offspring, whereas SD that were reared in LWC had lower paternity shares. The queens inseminated with equal proportions of semen from LD and SD (in group A) produced unequal proportions of workers with LD and SD paternity. The overrepresentation of $\mathrm{LD}$ in the worker offspring was observed in all insemination treatment groups as well as in the pooled data. Overall, SD had $10.5 \%$ less paternity share than expected. This result is not surprising given that SD have reduced reproductive potential (Schlüns et al. 2003; Gençer and Firatli 2005; Gençer and Kahya 2011).

Gençer and Kahya (2011) compared the reproductive potential of LD and SD that were the live materials of this present study. Both studies were simultaneously conducted with common material. We, therefore, can safely suggest the likely reasons for the overrepresentation of LD based on the findings of Gençer and Kahya (2011). According 
Table V. Patriline frequencies (\%) and the total numbers of worker offspring genotyped for each queen that was instrumentally inseminated with semen of $\operatorname{LD}(75 \%)$ and $\mathrm{SD}(25 \%)$. The drone numbers refer to the sequence in the semen collection step. The reverse sequence corresponds to the injection sequence in the injection step

\begin{tabular}{lccccc}
\hline Semen sequence (drone morph) & Queen 1 & Queen 2 & Queen 3 & Queen 4 & Total \\
\hline Drone 1 (LD1) & 49.38 & 9.59 & 2.63 & 9.21 & 18.24 \\
Drone 2 (LD2) & 4.94 & 10.96 & 11.84 & 5.26 & 8.14 \\
Drone 3 (LD3) & 4.94 & 8.22 & 9.21 & 14.47 & 9.12 \\
Drone 4 (SD1) & 2.47 & 8.22 & 7.89 & 10.53 & 7.17 \\
Drone 5 (LD4) & 7.41 & 9.59 & 14.47 & 14.47 & 11.40 \\
Drone 6 (LD5) & 3.70 & 8.22 & 6.58 & 10.53 & 7.17 \\
Drone 7 (LD6) & 6.17 & 10.96 & 5.26 & 1.32 & 5.86 \\
Drone 8 (SD2) & 2.47 & 10.96 & 7.89 & 1.32 & 5.54 \\
Drone 9 (LD7) & 3.70 & 4.11 & 10.53 & 11.84 & 7.49 \\
Drone 10 (LD8) & 8.64 & 2.74 & 5.26 & 13.16 & 7.49 \\
Drone 11 (LD9) & 3.70 & 4.11 & 5.26 & 6.58 & 4.89 \\
Drone 12 (SD3) & 2.47 & 12.33 & 13.16 & 2.63 & 7.49 \\
Total LD & 92.6 & 68.5 & 71.1 & 85.7 & 79.8 \\
Total SD & 7.4 & 31.5 & 28.9 & 14.3 & 20.2 \\
Total offspring $(n)$ & 81 & 73 & 76 & 77 & 307 \\
\hline
\end{tabular}

to the results of that study, the mean ejaculate volume of LD $(1.01 \mu \mathrm{l})$ was $53 \%$ greater than that of SD $(0.66 \mu \mathrm{l})$. It was previously evidenced that the drones contributing greater volume of semen had disproportionately higher paternity share than the drones contributing smaller volume of semen (Harbo 1988; Schlüns et al. 2004). In our present study, we eliminated the difference in ejaculate volume between LD and SD by taking the equal volume of semen $(0.6 \mu \mathrm{l})$ from each drone for instrumental insemination. This volume $(0.6 \mu \mathrm{l})$ was the optimum amount that could be taken from either LD or SD without any difficulty.

As the equal volume of ejaculate was taken from each drone for instrumental insemination, the difference in the number of spermatozoa between LD and SD is not expected to affect the paternity share if there is no difference in the concentration of spermatozoa. Nevertheless, Gençer and Kahya (2011) determined that there was a significant difference in the concentration of spermatozoa between LD and SD. LD had 7.256 × $10^{6}$ spermatozoa per $\mu$, whereas SD had $6.661 \times 10^{6}$ spermatozoa per $\mu$ l. LD had $8.2 \%$ more spermatozoa $(595 \times$ $10^{3}$ ) per $\mu l$ than LD. Due to the concentration difference, a queen that was inseminated with a mixture of semen from LD (50\%) and SD (50\%) should have $1.286 \times 10^{6}$ more LD spermatozoa in her lateral oviducts. This concentration difference $(8.2 \%)$ was close to the overall difference between observed and expected patriline frequency $(10.5 \%)$. Accordingly, the overrepresentation of LD can be explained by the difference in sperm concentration between LD and SD. Gençer and Firatli (2005) inseminated the queens with $8 \mu \mathrm{l}$ semen from either $\mathrm{LD}$ or SD. The difference in the number of spermatozoa between LD and SD influenced spermatozoa representation in the spermatheca of the queen. Queens inseminated with semen from LD $(4.57 \times$ $10^{6}$ ) had on average $0.96 \times 10^{6}$ more spermatozoa than the queens inseminated with semen from SD $\left(3.61 \times 10^{6}\right)$. We did not dissect the experimental queens to determine the number of spermatozoa in their spermathecae in our present study. Likely, the number of spermatozoa in the queens inseminated with 3:1 semen (LD:SD) would be higher than those inseminated with both 1:3 semen (LD:SD) and 1:1 semen (LD:SD) due to the concentration difference. However, we did not observe any difference in the egg-laying performance among queens. All queens displayed regular egg-laying in their colonies throughout the season. 


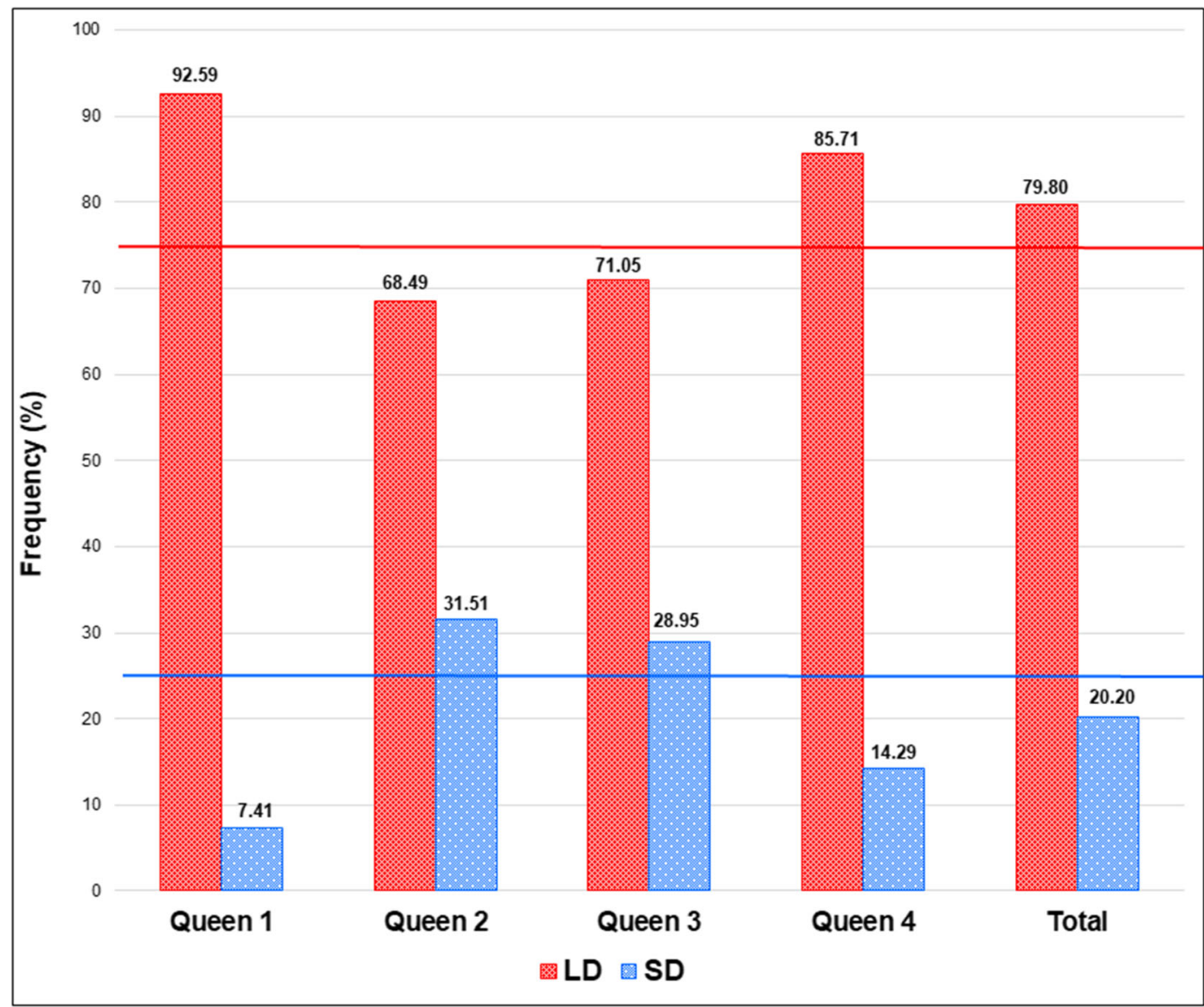

Figure 5. Proportions of offspring sired by large drones (LD) and small drones (SD) that were used to inseminate 4 queens with the mixture of $75 \% \mathrm{LD}$ and $25 \%$ SD semen. Horizontal red line refers to expected patriline frequency level for LD and horizontal blue line for SD.

The sperm traits other than the number and the concentration of spermatozoa may have an additional effect on the paternity share in favour of LD. The viability of spermatozoa is a critical fitness trait favouring sperm competition in insects (Hunter and Birkhead 2002). Siring success of individual males is associated with the proportion of live spermatozoa in the ejaculate (GarcíaGonzález and Simmons 2005) and the length of spermatozoa (Koffler et al. 2016). However, neither the viability nor the length of spermatozoa was found to be different between LD and SD, although their sperm concentrations were different (Gençer and Kahya 2011). Collectively, these results revealed that the competitive advantage of LD against SD is associated primarily with the concentration of spermatozoa, but not with the viability and length of spermatozoa. The viability of spermatozoa is not correlated with sperm concentration (Gençer et al. 2014) and mixing of ejaculates from different drones does not affect the viability of spermatozoa (Tofilski et al. 2012; Gençer et al. 2014). Tofilski et al. (2012) suggested the presence of interactions between ejaculates of different drones, which may be related to sperm competition. However, it is not known whether the interaction between ejaculates of drones can be mediated by differences in sperm concentration. Future work is required to compare LD and SD regarding other sperm traits such as motility, swimming speed and acrosome reaction, as well as seminal fluid properties. 
Table VI. Reproductive success of drone mother colonies (QRC and LWC) represented by the number of offspring per drone in the mother colony $\left(n_{3}\right)$ and the unit offspring proportion of drones in the mother colony $\left(\% / n_{1}\right)$

\begin{tabular}{ccccccc}
\hline $\begin{array}{c}\text { Colony } \\
\text { type }\end{array}$ & $\begin{array}{c}\text { Colony } \\
\text { number }\end{array}$ & $\begin{array}{c}\text { Number of } \\
\text { drones used in } \\
\text { inseminations } \\
\left(n_{1}\right)\end{array}$ & $\begin{array}{c}\text { Number of } \\
\text { offspring of } \\
\text { " } n_{1} \text { " drones }\left(n_{2}\right)\end{array}$ & $\begin{array}{c}\text { Offspring } \\
\text { proportion of } \\
\text { drones }(\%)\end{array}$ & $\begin{array}{c}\text { Number of } \\
\text { offspring per } \\
\text { drone }\left(n_{2} /\right. \\
\left.n_{1}=n_{3}\right)\end{array}$ & $\begin{array}{c}\text { Unit offspring } \\
\text { proportion of } \\
\text { drones }\left(\% / n_{1}\right)\end{array}$ \\
\hline QRC & 1 & 8 & 106 & 11.67 & 13.25 & 1.45875 \\
& 2 & 8 & 46 & 5.07 & 5.75 & 0.63375 \\
& 4 & 4 & 23 & 2.53 & 5.75 & 0.6325 \\
& 6 & 12 & 77 & 8.48 & 6.42 & 0.7066 \\
& 7 & 12 & 79 & 8.70 & 6.58 & 0.7250 \\
& 13 & 12 & 148 & 16.30 & 12.33 & 1.3583 \\
& 22 & 4 & 23 & 2.54 & 5.75 & 0.6350 \\
& 25 & 4 & 15 & 1.65 & 3.75 & 0.4125 \\
& 29 & 8 & 33 & 3.63 & 4.13 & 0.45375 \\
& Overall & 72 & 550 & 60.57 & 7.64 & 0.84125 \\
& 12 & 24 & 121 & 13.33 & 5.04 & 0.55541 \\
& 24 & 24 & 125 & 13.77 & 5.21 & 0.57375 \\
& 38 & 24 & 112 & 12.33 & 4.67 & 0.51375 \\
& Overall & 72 & 358 & 39.43 & 4.97 & 0.54763 \\
& Overall & 144 & 908 & 100.00 & 6.30 & - \\
\hline
\end{tabular}

The role of drones via mating is vital for colony fitness. A honey bee colony increases its fitness by rearing not only numbers but also a higher quality of drones (Kraus et al. 2003). Drone rearing in colonies is regulated by season, peaking in early summer and declining as the season advances (Boes 2010). Drones are typically reared from queen-laid unfertilised eggs in hexagonal larger cells. Unfertilised eggs are also deposited in smaller hexagonal cells by the inferior queen (drone layer) or by laying workers, resulting in small-sized drone offspring. Despite the existence of the queen, some workers lay unfertilised eggs in worker cells (Page Jr. and Erickson Jr. 1988). Since these worker-laid eggs are removed by nestmates (Ratnieks and Visscher 1989), only about $0.12 \%$ of adult drones produced are derived from eggs laid by workers in QRC (Visscher 1989).

In hopelessly queenless colonies that have no chance to rear a new queen, workers undergo ovarian development and become laying workers (Page Jr. and Erickson Jr. 1988). About half of the workers lay unfertilised eggs in LWC (Ratnieks 2002). More than 6000 worker-derived SD can be reared until LWC break down (Page Jr. and Metcalf 1984). Although LWC are not desirable regarding apicultural standpoint, SD that are reared in these colonies have practical and biological functions. LD in queenright colonies are hardly present at the end of the mating season due to drone eviction process (Boes 2010). SD, however, can be reared at suboptimal times of the year without having strong colonies. The queen losses in colonies that may happen at the end of mating season result in emergency queen rearing. SD have a chance to mate if young queens are present (Hemmling 1991). $\mathrm{SD}$, therefore, can supply sperm need of emergency queens at the late season. Intentional SD production may also be an alternative way to prolong the production period for queen rearing farms. In addition to potential use in the field, SD may be the actors of selective breeding. LD from a queenright colony represent only the genes of the queen, whereas SD from laying workers represent the gene frequencies of worker population of the colony (Harbo 
1991). Further, SD may potentially be of importance in maintaining genetic diversity at the sex locus in a population (Gloag et al. 2019).

We can conclude from this study that the concentration of spermatozoa in ejaculate affects the reproductive success of drones and the evolution forces drones to produce not only plentiful but also more concentrated semen. To our knowledge, this study is the first report to quantify the sperm competitiveness of SD that were reared in LWC against LD reared in QRC. SD were not found to be as successful as LD in sperm competition. Nevertheless, it does not imply that SD reared in LWC are useless.

\section{ACKNOWLEDGEMENTS}

We thank Ali Ergül for his guidence in microsatellite DNA analysis, and Ensar Başpınar for his help on statistical analysis.

\section{AUTHORS' CONTRIBUTION}

HVG conceived this research and designed experiments; YK participated in the design and interpretation of the data; HVG and YK performed experiments and analyses; HVG wrote the paper. Both authors read and approved the final manuscript.

\section{FUNDING INFORMATION}

This study was financially supported by the fund (TOVAG-108O447) from the Scientific and Technological Research Council of Turkey (TUBITAK) to HVG.

\section{COMPLIANCE WITH ETHICAL STANDARDS}

Conflict of interest The authors declare that they have no conflict of interest.

Concurrence chez les abeilles (Apis mellifera $\mathrm{L}$.): le rôle du dimorphisme de la taille corporelle chez les mâles.

polyandrie / compétition de spermatozoïdes / fréquence patrilinéaire / mâle / dimorphisme de taille.
Konkurrenz bei Honigbienen (Apis mellifera L.): Die Bedeutung des Grössendimorphismus bei Drohnen.

Polyandrie / Spermienkonkurrenz / Patrilinienfrequenz / Drohn / Grössendimorphismus.

\section{REFERENCES}

Baer, B. (2005) Sexual selection in Apis bees. Apidologie 36, 187-200

Baer, B., Collins, J., Maalaps, K., den Boer, S. P. A. (2016) Sperm use economy of honeybee (Apis mellifera) queens. Ecol. Evol. 6, 2877-2885

Baudry, E., Solignac, M., Garnery, L., Gries, M., Cornuet, J.-M., Koeniger, N. (1998) Relatedness among honeybees (Apis mellifera) of a drone congregation. Proc. R. Soc. Lond. B 265 , 2009-2014

Berg, S. (1991) Investigation on the rates of large and small drones at a drone congregation area. Apidologie 22, $437-438$

Berg, S., Koeniger, N., Koeniger, G., Fuchs, S. (1997) Body size and reproductive success of drones (Apis mellifera L). Apidologie 28, 449-460

Boes, K. E. (2010) Honeybee colony drone production and maintenance in accordance with environmental factors: an interplay of queen and worker decisions. Insectes Soc. 57, 1-9.

Boomsma, J. J., Ratnieks, F. L. W. (1996) Paternity in eusocial Hymenoptera. Phil. Trans. R. Soc. Lond. B 351, 947-975

Boomsma, J. J., Baer, B., Heinze, J. (2005) The evolution of male traits in social insects. Annu. Rev. Entomol. 50, 395-420

Brodschneider, R., Arnold, G., Hrassnigg, N., Crailsheim, K. (2012) Does patriline composition change over a honey bee queen's lifetime? Insects 3, 857-869

Coelho, J. R. (1996) The flight characteristics of drones in relation to mating. Bee Sci. 4, 21-25

Collins, A. M. (2000) Relationship between semen quality and performance of instrumentally inseminated honey bee queens. Apidologie 31, 421-429

Couvillon, M. J., Hughes, W. O. H., Perez-Sato J. A., Martin, S. J., Roy, G. G. F., Ratnieks, F. L. W. (2010) Sexual selection in honey bees: colony variation and the importance of size in male mating success. Behav. Ecol. $21,520-525$

Czekońska, K., Szentgyörgyi, H., Tofilski, A. (2019) Body mass but not wing size or symmetry correlates with life span of honey bee drones. B. Entomol. Res. 109, 383389

DeGrandi-Hoffman, G., Tarpy, D. R., Schneider, S. S. (2003) Patriline compositions of worker populations in honey bee (Apis mellifera) colonies headed by 
queens inseminated with semen from African and $\mathrm{Eu}-$ ropean drones. Apidologie 34, 111-120

Estoup, A., Garnery, L., Solignac, M., Cornuet, J.-M. (1995) Microsatellite variation in honey bee (Apis mellifera L.) populations: Hierarchical genetic structure and test of the infinite allele and stepwise mutation models. Genetics 140, 679-695

Franck, P., Coussy, H., Le Conte, Y., Solignac, M., Garnery, L., Cornuet, J.-M. (1999) Microsatellite analysis of sperm admixture in honeybee. Insect Mol. Biol. 8, 419-421

Franck, P., Solignac, M., Vautrin, D., Cornuet, J.-M., Koeniger, G., Koeniger, N. (2002) Sperm competition and last-male precedence in the honeybee. Anim. Behav. 64, 503-509

García-González, F., Simmons L W (2005) Sperm viability matters in insect sperm competition. Curr. Biol. 15, 271-275.

Gençer H. V., Firatli, Ç. (2005) Reproductive and morphological comparisons of drones reared in queenright and laying worker colonies. J. Apic. Res. 44, 163-167

Gençer, H. V., Kahya, Y. (2011) Are sperm traits of drones (Apis mellifera L.) from laying worker colonies noteworthy? J. Apic. Res. 50, 130-137

Gençer, H. V., Kahya, Y., Woyke, J. (2014) Why the viability of spermatozoa diminishes in the honeybee (Apis mellifera) within short time during natural mating and preparation for instrumental insemination. Apidologie 45, 757-770

Gessner B., Ruttner F., (1977) Transfer der Spermatozoen in die Spermatheka der Bienenkonigin, Apidologie 8, 1-18

Gloag, R. S., Christie J. R., Ding, G., Stephens, R. E., Buchmann, G., Oldroyd, B. P. (2019) Workers' sons rescue genetic diversity at the sex locus in an invasive honey bee population. Mol. Ecol. 28, 1585-1592

Goins, A., Schneider, S. S. (2013) Drone "quality" and caste interactions in the honey bee, Apis mellifera L. Insect. Soc. 60 , 453-461

Haberl, M., Tautz, D. (1998) Sperm usage in honey bees. Behav. Ecol. Sociobiol. 42, 247-255

Hall, H. G. (1986) DNA differences found between Africanized and European honeybees. Proc. Natl. Acad. Sci. USA 83, 4874-4877

Harbo, J. R. (1988) Sperm competition. Am. Bee J. 128, 803-804

Harbo, J. R. (1990) Artificial mixing of honey bee spermatozoa from honeybees and evidence for sperm competition. J. Apic. Res. 29, 151-158

Harbo, J. R. (1991) Laying workers produce a drone population that genetically represent their colony. Am. Bee J. 131, 776-777

Hayashi, M, Nakamura, J., Sasaki, K, Harano, K. I. (2016) Honeybee males use highly concentrated nectar as fuel for mating flights. J. Insect Physiol. 93-94, 50-55

Hemmling C. (1991) Production and sexual maturity of drones in queenless colonies. Apidologie 22, 435-436

Herrmann, M., Trenzcek, T., Fahrenhorst, H., Engels, W. (2005) Characters that differ between diploid and haploid honey bee (Apis mellifera) drones. Genet. Mol. Res. 4, 624-641

Holmes, M. J., Allsopp, M. H., Noach-Pienaar, L.-A., Wossler, T. C., Oldroyd, B. P., Beekman, M. (2011) Sperm utilization in honeybees (Apis mellifera scutellata and Apis mellifera capensis ) in South Africa. Apidologie 42, 23-28

Hunter, F. M., Birkhead, T. R. (2002) Sperm viability and sperm competition in insects. Curr. Biol. 12, 121-123

Jaffé, R., Moritz, R. F. A. (2010) Mating flights select for symmetry in honeybee drones (Apis mellifera). Naturwissenschaften 97, 337-343

Jarolimek, J., Otis, G. W. (2001) A comparison of fitness components in large and small honey-bee drones. Am. Bee J. 141, 891-892

Kalinowski, S. T., Taper, M. L., Marshall, T. C. (2007) Revising how the computer program CERVUS accommodates genotyping error increases success in paternity assignment. Mol. Ecol. 16, 1099-1006

Koeniger, N., Koeniger, G. (1991) An evolutionary approach to mating behavior and drone copulatory organs in Apis. Apidologie 22, 581-590

Koeniger, G., Koeniger, N., Fabritius, M. (1979) Some detailed observations of mating in the honey bee. Bee World 60, 53-57

Koeniger, N., Koeniger, G., Pechhacker, H. (1992) Utilisation of sperm in naturally mated honey bee queens (Apis mellifera carnica). Apidologie 23, 349-351

Koeniger, N., Koeniger, G., Gries, M., Tingek, S. (2005) Drone competition at drone congregation areas in four Apis species. Apidologie 36, 211-221

Koffler, S., Meneses, H. M., Kleinert, A. M., Jaffé, R (2016) Competitive males have higher quality sperm in a monogamous social bee. BMC Evol. Biol. 16, 195

Kraus, F. B., Neumann, P., Scharpenberg, H., Van Praagh, J., Moritz, R. F. A. (2003) Male fitness of honeybee colonies (Apis mellifera L.). J. Evol. Biol. 16, 914-920.

Laidlaw, H. H. Jr. (1944) Artificial insemination of the queen bee (Apis mellifera L): Morphological basis and results. J. Morphol. 74, 429-465

Laidlaw, H. H. Jr., Page, R. E. Jr. (1984) Polyandry in honey bees (Apis mellifera L.): sperm utilization and intracolony genetic relationship. Genetics 108, 985-997

Laidlaw, H. H. Jr., Page, R. E. Jr. (1997) Queen Rearing and Bee Breeding. Wicwas Press, Cheshire, Connecticut

McAneney-Lannen, G. E. (2004) Honeybee (Apis mellifera L.) drone size and its effects on aspects of male fitness. A Thesis Presented to the Faculty of Graduate Studies of the University of Guelph for the Degree of Master of Science; Guelph, Canada

Miller, C. W., Svensson, E. I. (2014) Sexual selection in complex environments. Annu. Rev. Entomol. 59, 427445

Moritz, R. F. A. (1981) Der Einfluss der Inzucht auf die Fitness der Drohnen von Apis mellifera carnica. Apidologie 12, 41-55 
Moritz, R. F. A. (1986) Intracolonial worker relationship and sperm competition in the honeybee (Apis mellifera L.). Experientia 40, 182-184

Page, R. E. Jr. (1986) Sperm utilization in social insects. Annu. Rev. Entomol. 31 , 297-320

Page, R. E. Jr. (2013) The Spirit of the Hive - The Mechanisms of Social Evolution. Harvard University Press, London, England

Page, R. E. Jr., Erickson, E. H. Jr. (1988) Reproduction by worker honeybees (Apis mellifera L.). Behav. Ecol. Sociobiol. 23, 117-126

Page, R. E. Jr., Metcalf, R. A. (1982) Multiple mating, sperm utilization, and social evolution. Am. Nat. 119, 263-281

Page, R. E. Jr., Metcalf, R. A. (1984) A population investment sex ratio for the honey bee (Apis mellifera L.). Am. Nat. 124, 680-702

Page, R. E. Jr., Kimsey, R. B., Laidlaw, H. H. Jr. (1984) Migration and dispersal of spermatozoa in spermathecae of queen honeybees (Apis mellifera L.). Experientia 40, 182-184

Palmer, K. A., Oldroyd, B. P. (2000) Evolution of multiple mating in the genus Apis . Apidologie 31 , 235-242

Parker, G. A. (1970) Sperm competition and its evolutionary consequences in the insects. Biol. Rev. 45, 525-567

Peer, D. F. (1956) Multiple mating of queen honey bees. J. Econ. Entomol. 49, 741-743

Ratnieks, F. L. W. (2002) Conflict in the bee hive: worker reproduction and worker policing. The Beekeepers Quarterly 70, 16-17

Ratnieks, F. L. W., Visscher, P. K. (1989) Worker policing in honeybees. Nature 342, 796-797

Rinderer, T. E., Collins, A. M., Pesante, D. (1985) A comparison of Africanized and European drones: weights, mucus gland and seminal vesicle weights, and counts of spermatozoa. Apidologie 16, 407-412

Ruttner, F. (1956) The mating of the honeybee. Bee World 37, 3-15

Ruttner, F., Koeniger, G. (1971) Die Füllung der Spermatheca der Bienenkönigin. Aktive Wandering oder Passiver Transport der Spermatozoen? Z. Vergl. Physiolgie 72, 411-422

Sasaki, K., Satoh, T., Obara, Y. (1995) Sperm utilization by honey bee queens; DNA fingerprinting analysis. Appl. Entomol. Zool. 30, 335-341

Schlüns, H., Schlüns, E. A., Van Praagh, J., Moritz, R. F. A. (2003) Sperm numbers in drone honeybees (Apis mellifera ) depend on body size. Apidologie 34, 577584

Schlüns, H., Koeniger, G., Koeniger, N., Moritz, R. F. A. (2004) Sperm utilization pattern in the honeybee (Apis mellifera). Behav. Ecol. Sociobiol. 56, 458-463

Shafir, S., Kabanoff, L., Duncan, M., Oldroyd, B. P. (2009) Honey bee (Apis mellifera) sperm competition in vitro two are no less viable than one. Apidologie 40, 556-561
Shuster, S. M., Wade, M. J. (2003) Mating Systems and Strategies. Princeton University Press, USA

Slone, J. D., Stout, T. L., Huang, Z. Y., Schneider, S. S. (2012) The influence of drone physical condition on the likelihood of receiving vibration signals from worker honey bees, Apis mellifera. Insect. Soc. 59, 101-107

Solignac, M., Vautrin D., Loiseau, A., Mougel, F., Baudry, E. Estoup, A., Garnery, L., Haberl, M., Cornuet, J.-M. (2003) Five hundred and fifty microsatellite markers for the study of the honeybee (Apis mellifera L.) genome. Mol. Ecol. Notes 3, 307-313

Strassmann, J. (2001) The rarity of multiple mating by females in the social Hymenoptera. Insect. Soc. 48, $1-13$

Streinzer, M., Spaethe, J. (2015) A scientific note on peripheral compound eye morphology of small and normal-sized honey bee drones. J. Apic. Res. 54, 5961

Sundin, J. (2009) The evolution of animal mating systems. Introductory Research Essay No. 96 (ISSN 1404 4919), Uppsala, Sweden

Taber, S. (1954) The frequency of multiple mating of queen honey bees. J. Econ. Entomol. 47, 995-998

Tofilski, A., Chuda-Mickiewicz, B., Czekońska, K., Chorbiński, P. (2012) Flow cytometry evidence about sperm competition in honey bee (Apis mellifera). Apidologie 43, 63-70

Visscher, P. K. (1989) A quantitative study of worker reproduction in honey bee colonies. Behav. Ecol. Sociobiol. 25, 247-254

Wang, J., (2004) Sibship reconstruction from genetic data with typing errors. Genetics 166, 1963-1979

Woyciechowski, M., Król, E. (1996) On intraoviductal sperm competition in the honeybee (Apis mellifera). Folia Biol.-Kraków 44, 1-2

Woyke, J. (1956) Anatomo-physiological changes in queen bees returning from mating flights, and the process of multiple mating. Bull. Acad. Polon. Sci. 4, 81-87

Woyke, J. (1962) Natural and artificial insemination of queen honeybees. Bee World 43, 21-25

Woyke, J. (1964) Causes of repeated mating flights by queen honeybees. J. Apic. Res. 3, 17-23

Woyke, J. (1983) Dynamics of entry of spermatozoa into the spermatheca of instrumentally inseminated queen honeybees. J. Apic. Res. 22, 150-154

Woyke, J. (2008) Why the eversion of endophallus of honey bee drone stops at the partly everted stage and significance of this. Apidologie 39, 627-636

Zaitoun, S., Al-Ghzawi, A., Kridli, R. (2009) Monthly changes in various drone characteristics of Apis mellifera ligustica and Apis mellifera syriaca. Entomol. Sci. 12, 208-214

Publisher's note Springer Nature remains neutral with regard to jurisdictional claims in published maps and institutional affiliations. 